\title{
Rancang Bangun Sistem Informasi $E$ - Voting Pada Pemilihan Ketua RW Kelurahan Pejaten Timur
}

\author{
Eva Rahmawati ${ }^{1 *}$, Sidik $^{2)}$, Yudha Kamal Fauzan ${ }^{3)}$ \\ ${ }^{122) 3)}$ Program Studi Teknik Informatika, STMIK Nusa Mandiri \\ ${ }^{*}$ Correspondence Author: eva.ehw@bsi.ac.id, Jakarta, Indonesia \\ DOI: https://doi.org/10.37012/jtik.v6i2.214
}

\begin{abstract}
Abstrak
Pemilihan Ketua RW masih menggunakan pemungutan suara (voting) secara konvesional, yaitu dengan menggunakan media kertas untuk proses pemilihan dan penghitungan hasil pemilihan secara manual. Dalam pelaksanaan sistem pemilihan Ketua RW secara konvensional terdapat banyak kelemahan seperti, penghitungan hasil pemilihan relatif lama dan penghitungan terkadang masih terjadi kesalahan. Kemajuan teknologi informasi saat ini telah membawa perubahan yang cukup besar bagi manusia, termasuk cara untuk melaksanakan voting. Penggunaan teknologi komputer pada pelaksanaan voting dikenal dengan istilah electronic voting atau disebut dengan $e$-voting. Sehingga proses pemilihan Ketua RW menjadi lebih cepat dan efisien. Sistem ini dirancang dengan menggunakan bahasa pemrograman PHP, Sublime Text 3, dan filefile database dirancang dengan menggunakan MySQL Xampp. Perancangan sistem informasi ini dibuat untuk membantu, mempermudah, dan mengantisipasi kesalahan-kesalahan yang terjadi pada pemilihan Ketua RW.
\end{abstract}

Kata Kunci : Sistem Informasi, E-Voting, PHP, MySQL, Xampp

\begin{abstract}
Election of RW Chairperson still uses conventional voting, namely by using paper media for the selection process and counting the election results manually. In the conventional implementation of the Election System, the Chairperson of the RW has many weaknesses, such as the calculation of the results of the election is relatively long and the calculation sometimes still occurs error. Current advances in information technology have brought significant changes to people, including ways to conduct voting. The use of computer technology in the implementation of voting is known as electronic voting or called e-voting. So that the selection process for RW Chairperson is faster and more efficient. This system is designed using the PHP programming language, Sublime Text 3, and database files designed using MySQL Xampp. The design of this information system is made to help, facilitate, and anticipate errors that occur in the election of $R W$ Chairperson.
\end{abstract}

Kata Kunci : Sistem Informasi, E-Voting, PHP, MySQL, Xampp

\section{PENDAHULUAN}

Menurut Lincoln (2014:1), "Demokrasi adalah pemerintahan suatu negara yang diselenggarakan dari rakyat, oleh rakyat, dan untuk rakyat”. Menurut Moertopo (2015:1) Pemilihan umum adalah adalah sarana yang tersedia bagi rakyat untuk menjalankan kedaulatannya sesuai dengan azas yang bermaktub dalam Pembukaan UUD 1945. Pemilu itu sendiri pada dasarnya adalah suatu Lembaga Demokrasi yang memilih anggota-anggota perwakilan rakyat dalam MPR, DPR, DPRD, yang pada gilirannya bertugas untuk bersama-sama dengan pemerintah, menetapkan politik dan jalannya pemerintahan negara. 
Pemungutan suara atau voting di Indonesia, khususnya pada pemilihan umum (pemilu) legislatif maupun pemilihan eksekutif, masih menggunakan metode pemungutan suara manual. Pemungutan suara di Indonesia pada umumnya dilakukan secara manual, baik dalam ruang lingkup terkecil maupun terbesar. Contohnya adalah pemungutan suara Ketua RW yang masih dilakukan secara manual. Menurut Shalahuddin (2015:27), menyatakan bahwa "Sistem e-voting dapat diberdayagunakan sejak pendataan calon pemilih, pendaftaran calon pemilih, pelaksanaan pemungutan suara sampai dengan perhitungan hasil pemungutan suara". E-voting telah menjadi suatu alternatif untuk mengambil keputusan penting dalam kehidupan manusia.

Proses penghitungan suara yang berjalan lambat mengakibatkan proses tersebut harus menunggu terlebih dahulu sehingga memperlambat penghitungan suara, untuk mengatasi permasalahan di atas salah satu solusi yang dapat diterapkan adalah dengan menyelenggarakan pemilihan secara online atau yang lebih dikenal dengan istilah electronic voting atau e-voting. Penerapan solusi e-voting memadukan berbasis web dengan menggunakan bahasa pemograman PHP dan basis data Mysql.

\section{METODE}

Metode-metode yang digunakan untuk mendapatkan data dalam pembuatan penelitian ini sebagai berikut:

1. Observasi

Penulis melakukan pengamatan secara langsung. Sehingga memperoleh data yang lebih akurat dan spesifik yang dibutuhkan pada web ini.

2. Wawancara

Penulis melakukan tanya jawab dan wawancara kepada Bapak Jamiat Amir Hudaya selaku Ketua RW 10 dan pihak-pihak yang terkait untuk mendapatkan dan melengkapi informasi atau data yang dibutuhkan.

3. Studi Pustaka

Penulis mendapatkan data dengan membaca buku-buku, jurnal, informasi dan media internet dan referensi yang berhubungan dengan studi literature berkaitan dengan perancangan program.

Menurut Krismaji (2014:2) menjelaskan bahwa Sistem informasi adalah cara-cara yang diorganisasi untuk mengumpulkan, memasukkan, dan mengolah serta menyimpan data, dan cara-cara yang diorganisasi untuk menyimpan, mengelola, mengendalikan, dan melaporkan informasi sedemikian rupa sehingga sebuah organisasi dapat mencapai tujuan yang telah ditetapkan. 
Menurut Ridwan, Arifin, \& Yulianto (2015:6) menyatakan bahwa "e-voting merupakan sebuah sistem yang memanfaatkan perangkat elektronik dan mengolah informasi digital untuk membuat surat suara, memberikan suara, menghitung perolehan suara dan memelihara serta menghasilkan jejak audit”.

Menurut Fatima (2015:2) menyatakan bahwa "Unified Modeling Language (UML) adalah sebuah bahasa yang berdasarkan grafik atau gambar untuk memvisualisasi, menspesifikasikan, membangun, dan pendokumentasian dari sebuah sistem pengembangan software berbasis $\mathrm{OO}$ (Object-Oriented). UML sendiri juga memberikan standar penulisan sebuah sistem blue print, yang meliputi konsep bisnis proses, penulisan kelas-kelas dalam bahasa program yang spesifik, skema database, dan komponen komponen yang diperlukan dalam sistem software".

Adapun hal-hal yang di pergunakan dalam perancangan berorientasi objek berbasis UML sebagai berikut:

\section{Use case diagram}

Menurut Rosa dan M. Shalahudin (2014:7), menyatakan "Use case atau diagram use case merupakan pemodelan untuk kelakuan (behavior) sistem informasi yang akan dibuat. Use case mendeskripsikan sebuah interaksi antara satu atau lebih aktor dengan sistem informasi yang akan dibuat".

2. Activity diagram

Menurut Rosa dan M. Shalahudin (2014:10), menyatakan bahswa "Diagram aktivitas atau activity diagram menggambarkan workflow (aliran kerja) atau aktivitas dari sebuah sistem atau proses bisnis atau menu yang ada pada perangkat lunak".

3. Class diagram

Menurut Rosa dan M. Shalahudin (2014:12), menyatakan bahwa "Diagram kelas atau class diagram menggambarkan struktur sistem dari segi pendefinisian kelas-kelas yang akan dibuat untuk membangun sistem".

4. Package diagram

Menurut Haviluddin (2014:4) menyatakan bahwa "Paket diagram biasanya digunakan untuk menggambarkan tingkat organisasi yang tinggi dari suatu proyek software".

5. Sequence diagram

Menurut Rosa dan M. Shalahudin (2014:13), "Diagram sekuen menggambarkan kelakuan objek pada use case dengan mendeskripsikan waktu hidup objek dengan massage yang dikirimkan dan diterima antar objek".

6. Component diagram 


Menurut Havilludin (2014:4) menyatakan bahwa "Component diagram
menggambarkan struktur fisik dari kode, pemetaan pandangan logis dari kelas proyek untuk kode aktual di mana logika ini dilaksanakan”.

7. Deployment diagram.

Menurut Sukamto dan Shalahuddin (2014:12), menyatakan bahwa "Diagram deployment atau deployment diagram menunjukkan konfigurasi komponen dalam proses eksekusi aplikasi. Diagram deployment juga dapat digunakan untuk memodelkan hal-hal seperti sistem tambahan dan sistem client / server".

Menurut Rosa dan Shalahuddin (2015:12) menyatakan bahwa "ERD adalah bentuk paling awal dalam melakukan perancangan basis data relasional. Jika menggunakan OODMBS maka perancangan ERD tidak perlu dilakukan”.

\section{HASIL DAN PEMBAHASAN}

Analisa kebutuhan software untuk website dengan beberapa prosedur diantaranya:

1. Halaman Pengunjung

Pengunjung dapat melihat hasil perhitungan suara Pemilihan Ketua RW.

2. Halaman Pemilih

a. Pemilih dapat melakukan login dengan kode unik yang sudah dibuat.

b. Pemilih dapat melihat Profil dari Calon Ketua RW.

c. Pemilih dapat melakukan voting.

3. Halaman Administrator

a. Admin dapat mengelola data pemilih.

b. Admin dapat mengelola data calon Ketua RW.

c. Admin dapat mengelola data wilayah.

d. Admin dapat melihat dan menyimpan grafik Hasil Perolehan e-voting.

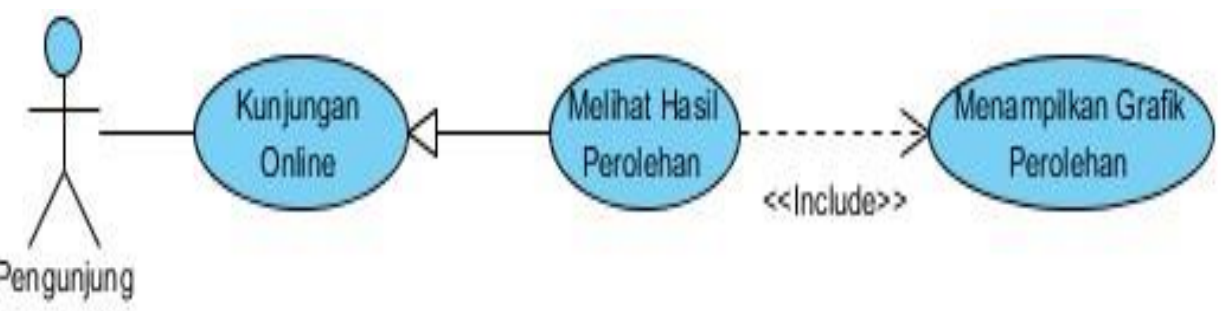

Gambar 1. Use Case Diagram Pengunjung 


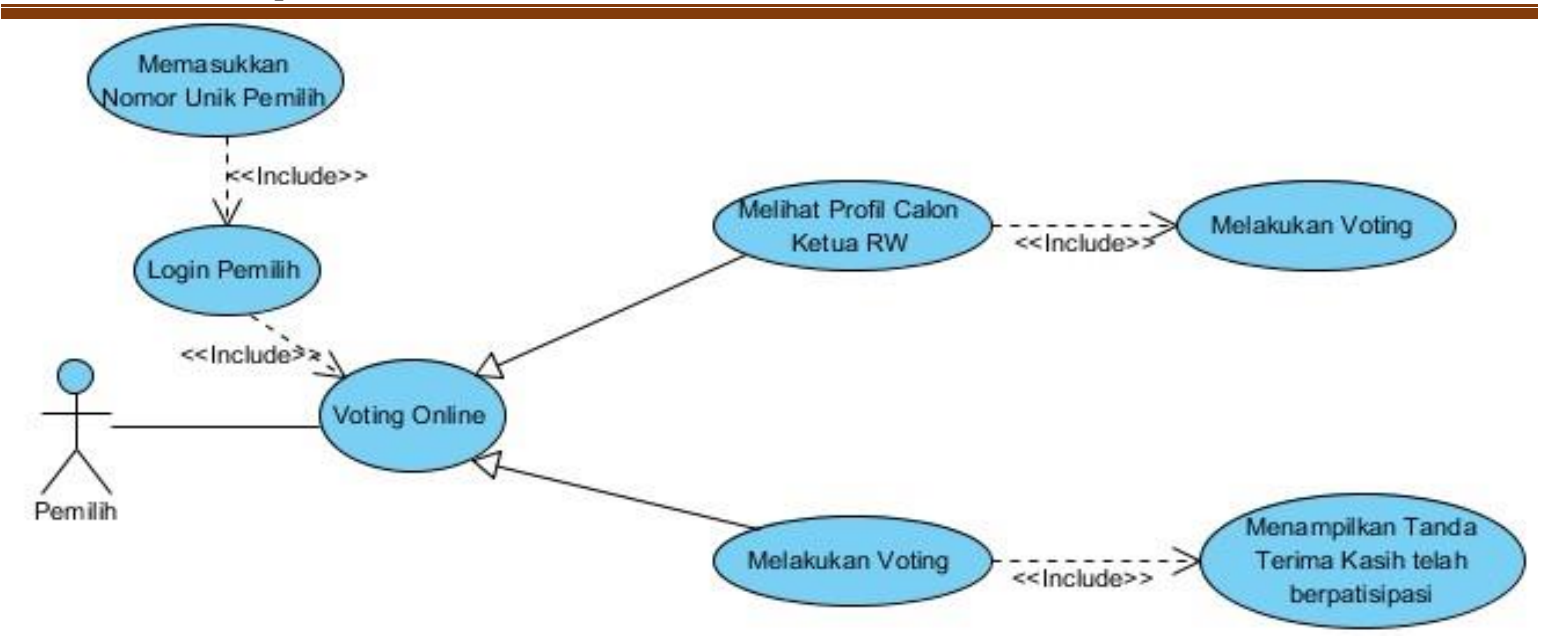

Gambar 2. Use Case Diagram Pemilih

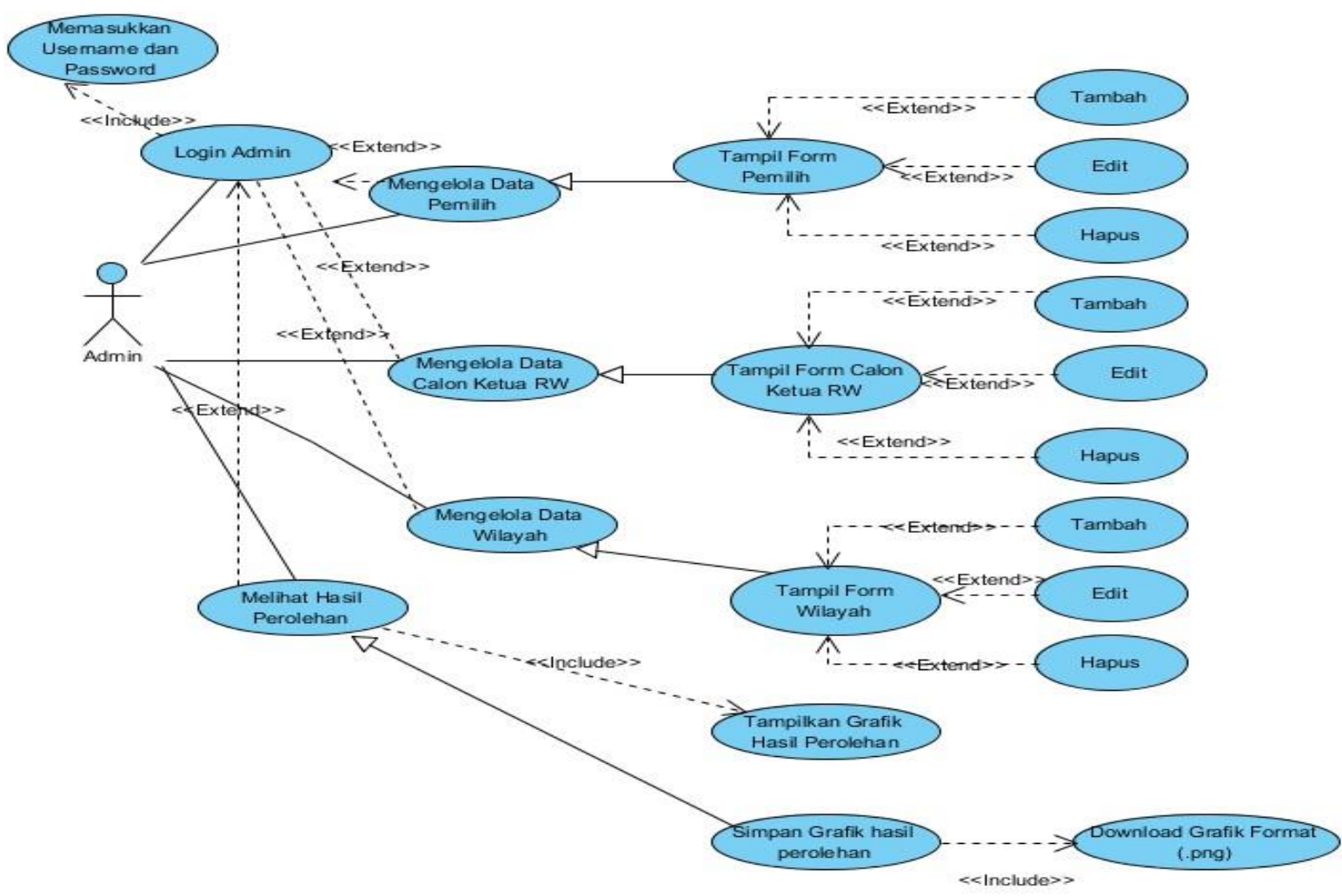

Gambar 3. Use Case Diagram Admin

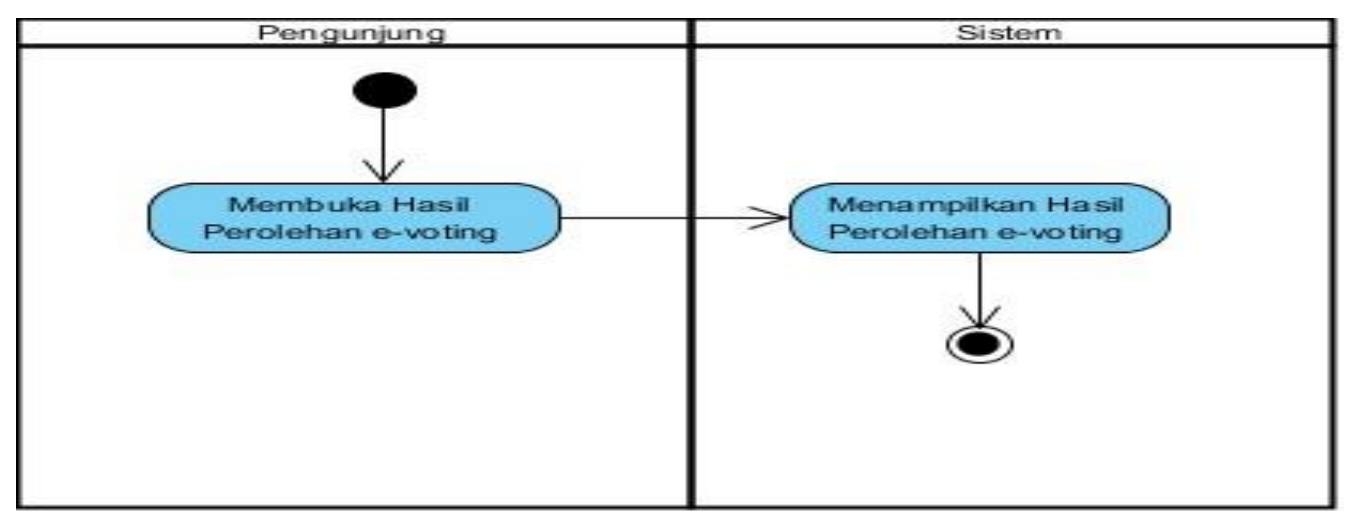

Gambar 4. Activity Diagram Pengunjung 
Volume 6 No 2; September 2020

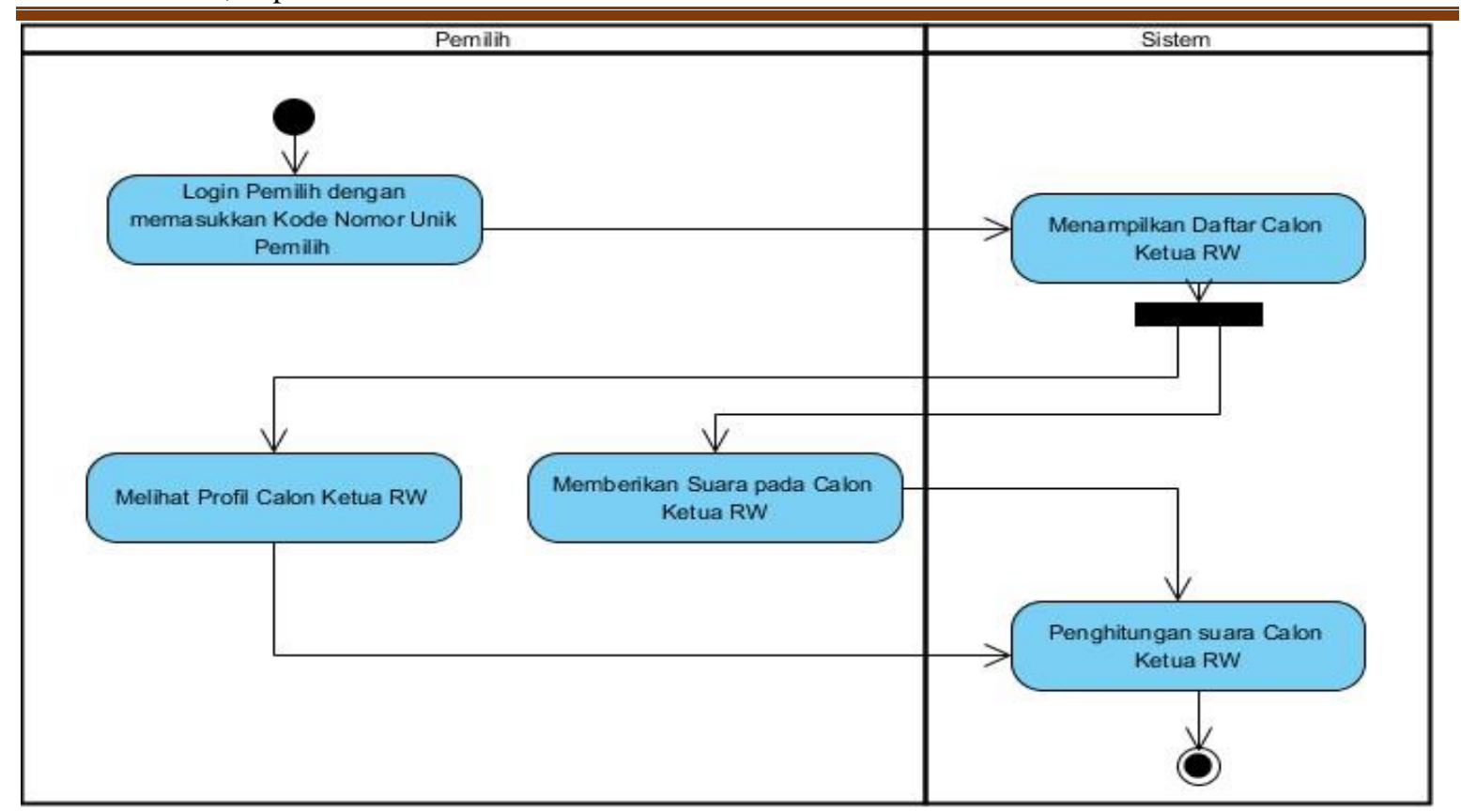

Gambar 5. Activity Diagram Pemilih

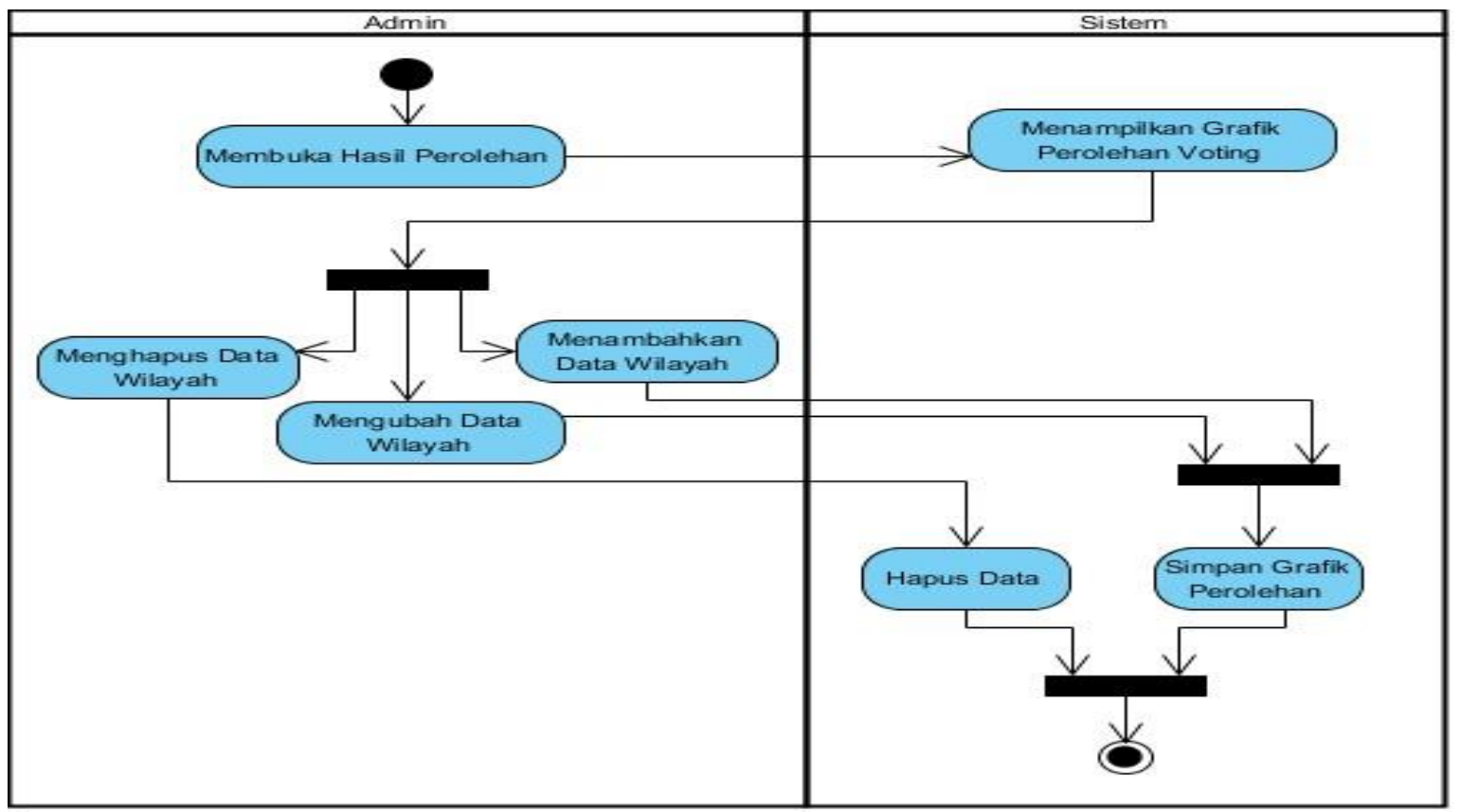

Gambar 6. Activity Diagram Admin Mengelola Data Wilayah 


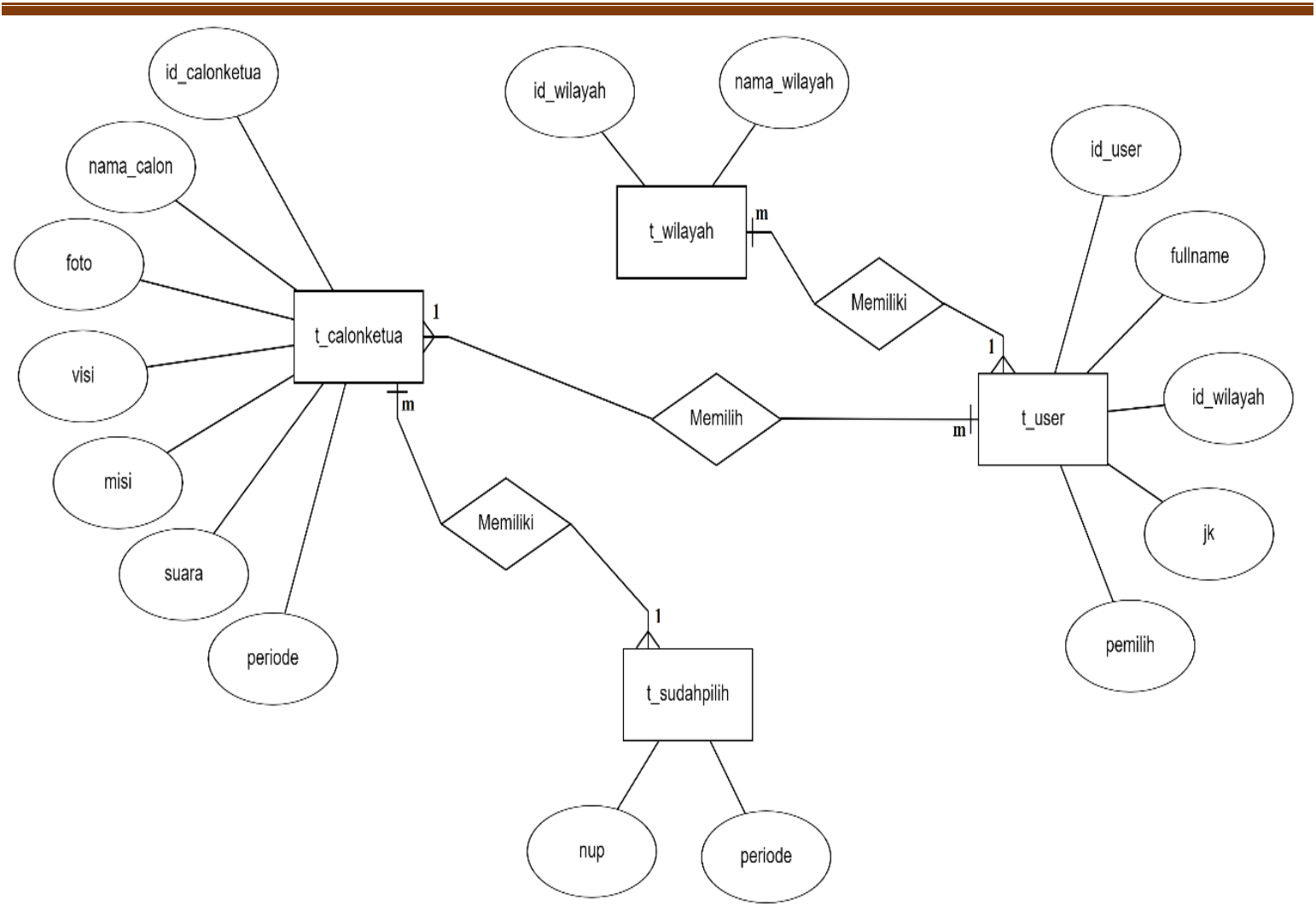

Gambar 7. Entity Relationship Diagram

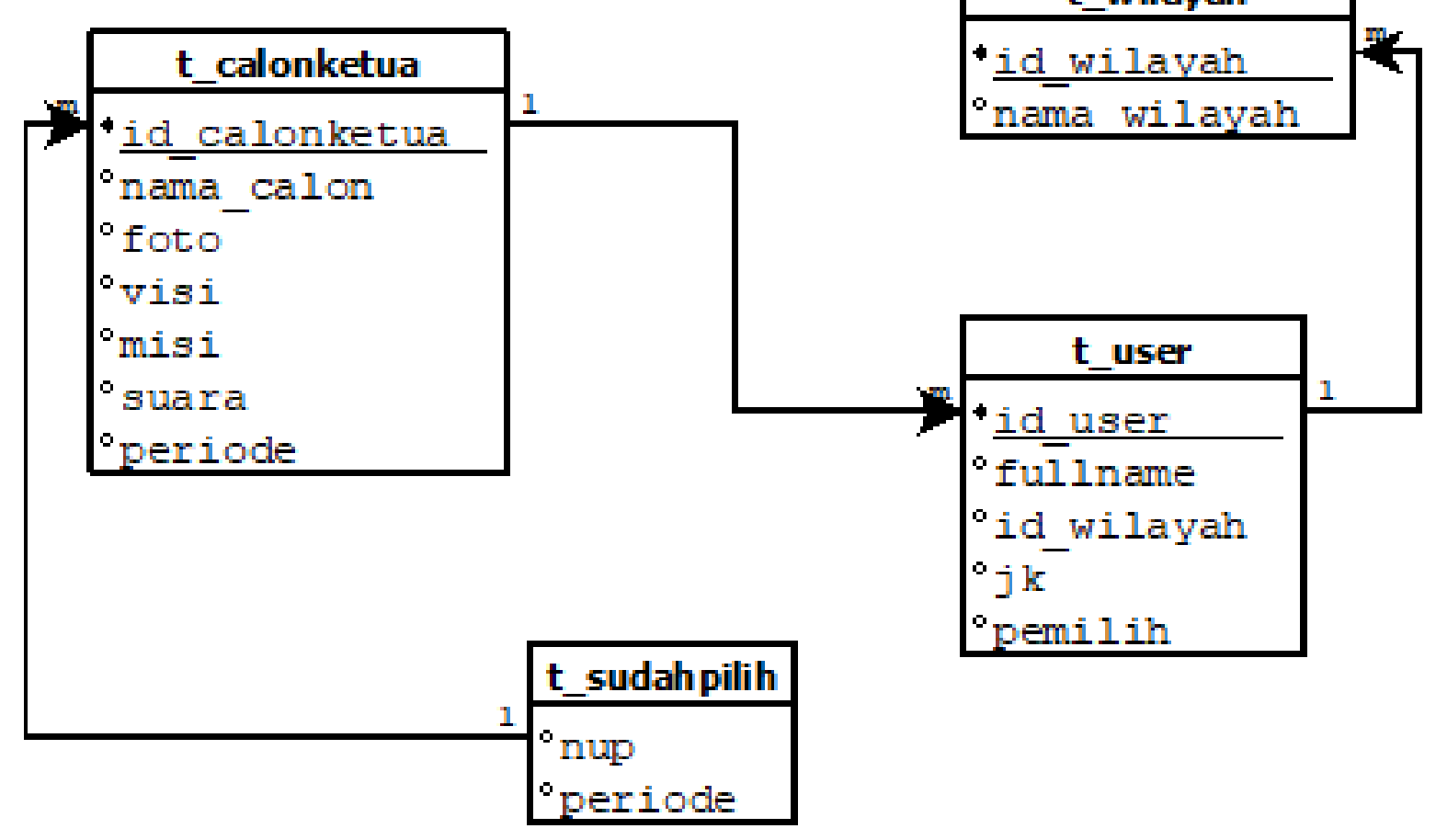

Gambar 8. LRS (Logical Record Structure) 


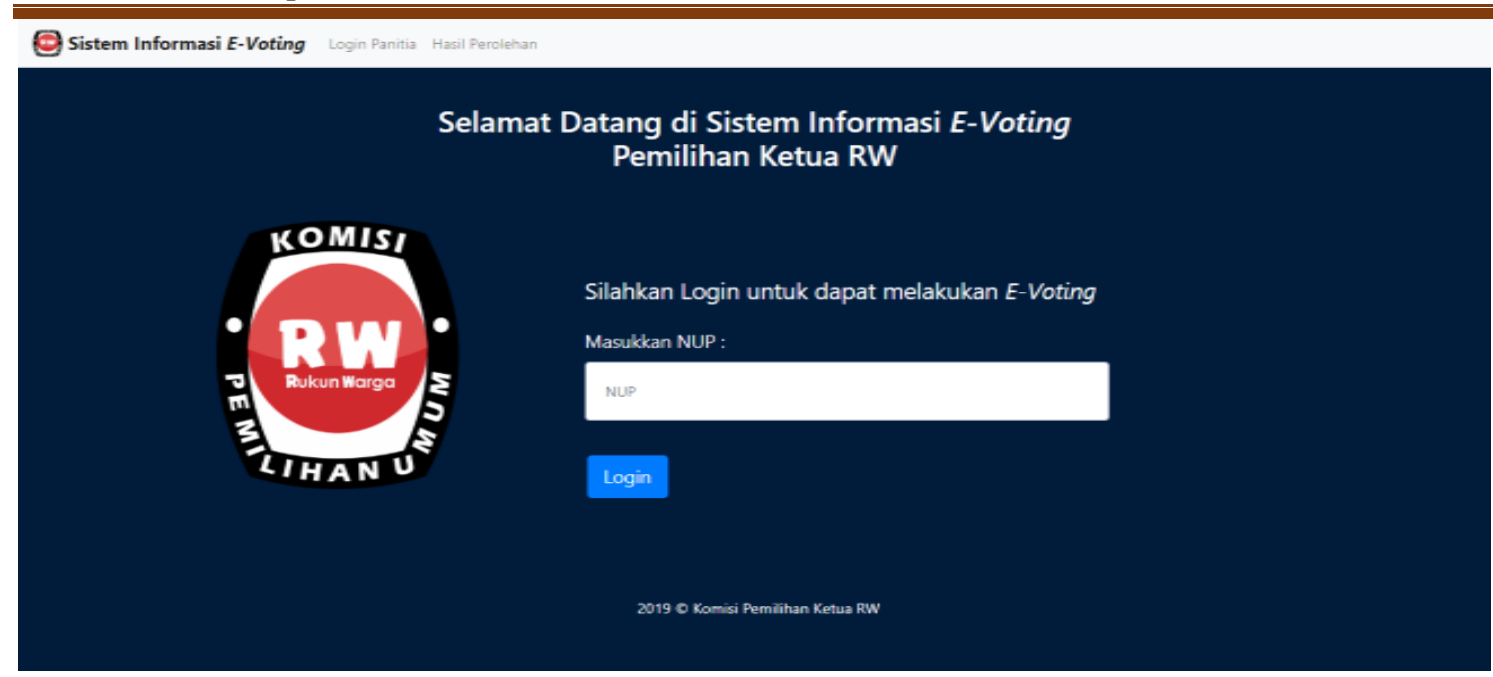

Gambar 9. Halaman Login Pemilih

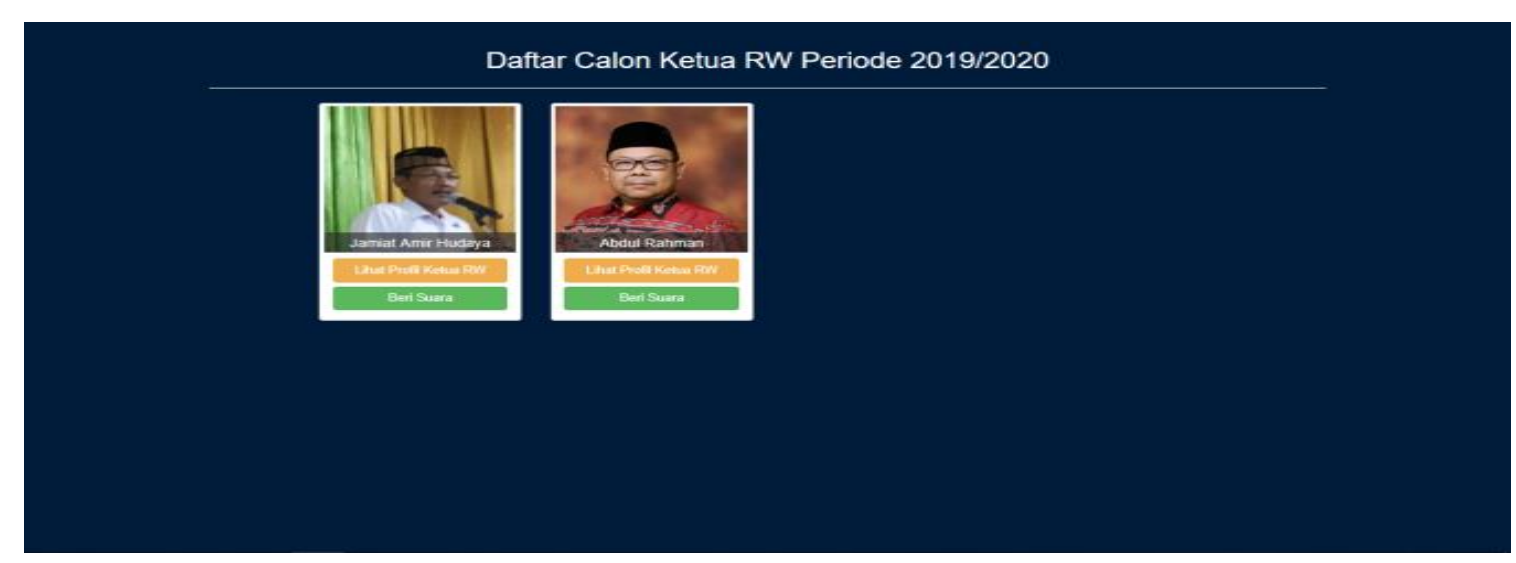

Gambar 10. Halaman Daftar Calon Ketua RW

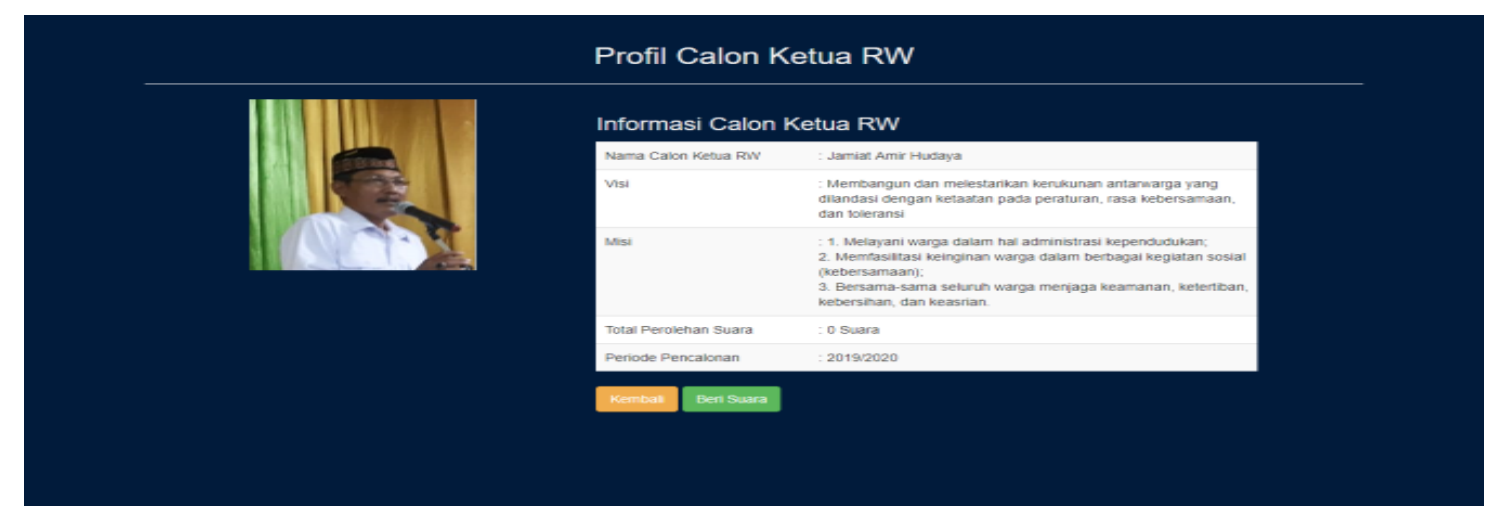

Gambar 11. Halaman Profil Calon Ketua RW 
Tabel 1. Hasil Pengujian Blackbox Testing Form Login Pemilih

\begin{tabular}{|c|c|c|c|c|c|}
\hline No & Skenario Pengujian & Test Case & Hasil yang di Harapkan & $\begin{array}{c}\text { Hasil } \\
\text { Pengujian }\end{array}$ & Kesimpulan \\
\hline 1 & $\begin{array}{l}\text { Nomor Unik } \\
\text { Pemilih (NUP) tidak } \\
\text { diisi, kemudian klik } \\
\text { tombol login }\end{array}$ & $\begin{array}{l}\text { Nomor Unik } \\
\text { Pemilih (NUP) } \\
\text { (kosong) }\end{array}$ & $\begin{array}{l}\text { Sistem akan menolak } \\
\text { akses dan akan } \\
\text { memunculkan pesan } \\
\text { notif "Please fill out } \\
\text { this field". }\end{array}$ & Sesuai harapan & valid \\
\hline 2 & $\begin{array}{l}\text { Memasulkkan } \\
\text { Nomor Unik } \\
\text { Pemilih (NUP) } \\
\text { yang sudah } \\
\text { melakukan voting }\end{array}$ & $\begin{array}{l}\text { Mengetikkan } \\
\text { Nomor Unik } \\
\text { Pemilih (NUP) } \\
\text { diisi kemudian } \\
\text { klik tombol } \\
\text { login }\end{array}$ & $\begin{array}{l}\text { Sistem akan } \\
\text { menolak akses } \\
\text { dan akan } \\
\text { memunculkan } \\
\text { pesan notifikasi "Anda } \\
\text { sudah memberikan } \\
\text { suara". }\end{array}$ & $\begin{array}{l}\text { Sesuai } \\
\text { harapan }\end{array}$ & Valid \\
\hline 3 & $\begin{array}{l}\text { Mengetikkan } \\
\text { salah satu } \\
\text { kondisi salah } \\
\text { pada } \\
\text { Nomor Unik } \\
\text { Pemilih (NUP) } \\
\text { kemudian } \\
\text { klik tombol } \\
\text { Login }\end{array}$ & $\begin{array}{l}\text { NUP: } 1245678 \\
\text { (salah) }\end{array}$ & $\begin{array}{l}\text { Sistem akan } \\
\text { menolak akses } \\
\text { dan akan } \\
\text { memunculkan } \\
\text { pesan "Anda tidak } \\
\text { berhak memberikan } \\
\text { suara". }\end{array}$ & $\begin{array}{l}\text { Sesuai } \\
\text { harapan }\end{array}$ & Valid \\
\hline 4 & $\begin{array}{c}\text { Mengetikan } \\
\text { Nomor Unik } \\
\text { Pemilih (NUP) } \\
\text { dengan data } \\
\text { yang benar } \\
\text { kemudian } \\
\text { klik tombol } \\
\text { login }\end{array}$ & NUP: 1234567 & $\begin{array}{l}\text { Sistem menerima } \\
\text { akses login dan } \\
\text { kemudian } \\
\text { langsung } \\
\text { menampilkan } \\
\text { halaman Daftar Calon } \\
\text { Ketua RW. }\end{array}$ & $\begin{array}{c}\text { Sesuai } \\
\text { harapan }\end{array}$ & Valid \\
\hline
\end{tabular}

\section{KESIMPULAN DAN REKOMENDASI}

Dari pembahasan diatas mengenai sistem informasi $e$-voting, penulis menarik kesimpulan dari keseluruhan pokok pembahasan sebagai berikut:

Metode pemungutan suara atau pemilihan calon ketua RW sebelumnya masih dilakukan secara manual. e-voting mengurangi permasalahan dalam penghitungan akibat kesalahan manusia (human error). Selain itu mengurangi biaya yang dibutuhkan saat melakukan pemilihan calon ketua RW. Pembuatan Sistem Informasi website ini dapat membantu menyelesaikan pemilihan yang ada pada Rukun Warga 10 Kelurahan Pejaten Timur yang saat ini akan dapat dilakukan sistem secara online. 


\section{REFERENSI}

Haviluddin. (2014). Summary for Policymakers. Memahami Penggunaan UML (Unified Modelling Language) HAVILUDDIN Program, 9(2), 1-6. https://doi.org/10.1017/CBO9781107415324.004

Inc, V. here. (2015). Secure Electronic Voting. Nani Purwanti, 27.

Krismaji. (2014). Krismaji 2015. Abdullah, (tahun 2016), 7-25.

Lincoln, A. (2014). Implementasi Kewenangan Dewan Kehormatan Penyelenggara Pemilu Dalam Menegakkan Kode Etik Penyelenggara Pemilu Legislatif 2014. Sukarno, R.M. Moertopo, A. (2015). Peran Pemilihan Umum Raya Dalam Membangun Kesadaran Berorganisasi Mahasiswa. A.M. Mulyana.

Ridwan, A. \& Y. (2015). Sistem Informasi E-Voting Pada Pemihan Kepala Desa di Tangerang Berbasis Web. Bsi, 6.

Rosa A.S dan M. Shalahudin. (2014). Rekayasa Perangkat Lunak (Terstruktur \& Berorientasi Objek). Politeknik Negri Sriwijaya, bab II(8-26), 296.

Rosa, \& Shalahudin. (2015). Sistem Informasi E-Voting dengan Menggunakan ERD. Bsi, 14-137.

Suendri. (2018). Implementasi Diagram UML (Unified Modelling Language) Pada Perancangan Sistem Informasi Remunerasi Dosen Dengan Database Oracle (Studi Kasus: UIN Sumatera Utara Medan). Jurnal Ilmu Komputer Dan Informatika, 3(1), $1-9$.

Sukamto. (2014). Implementasi Diagram UML (Unified Modelling Language) Pada Perancangan Sistem Informasi E-Voting. 9-45. 